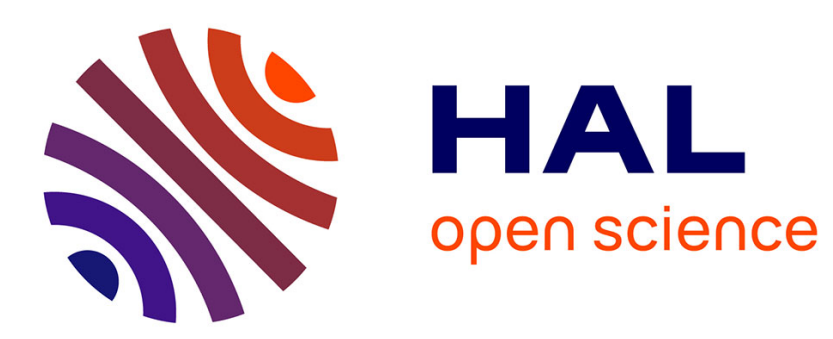

\title{
Peroxisomes and peroxisomal disorders: The main facts
}

Marco Fidaleo

\section{To cite this version:}

Marco Fidaleo. Peroxisomes and peroxisomal disorders: The main facts. Experimental and Toxicologic Pathology, 2010, 62 (6), pp.615. 10.1016/j.etp.2009.08.008 . hal-00644263

\section{HAL Id: hal-00644263 https://hal.science/hal-00644263}

Submitted on 24 Nov 2011

HAL is a multi-disciplinary open access archive for the deposit and dissemination of scientific research documents, whether they are published or not. The documents may come from teaching and research institutions in France or abroad, or from public or private research centers.
L'archive ouverte pluridisciplinaire HAL, est destinée au dépôt et à la diffusion de documents scientifiques de niveau recherche, publiés ou non, émanant des établissements d'enseignement et de recherche français ou étrangers, des laboratoires publics ou privés. 


\section{Author's Accepted Manuscript}

Peroxisomes and peroxisomal disorders: The main facts

Marco Fidaleo

PII: $\quad$ S0940-2993(09)00235-8

DOI: $\quad$ doi:10.1016/j.etp.2009.08.008

Reference: $\quad$ ETP 50398

To appear in: Experimental and Toxicologic Pathology

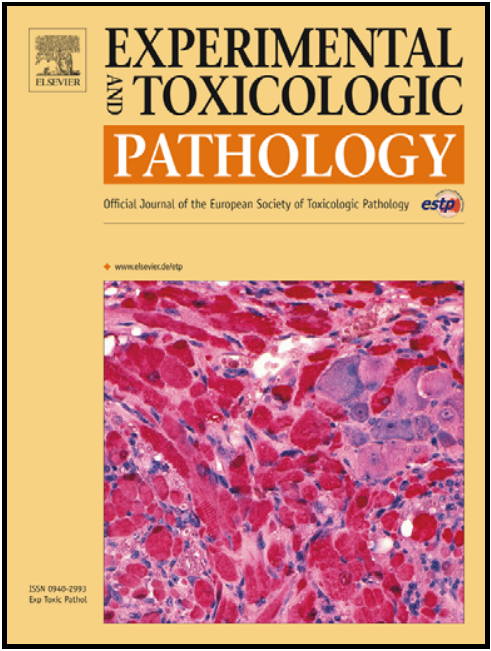

www.elsevier.de/etp

Received date: 31 January 2009

Accepted date: 16 August 2009

Cite this article as: Marco Fidaleo, Peroxisomes and peroxisomal disorders: The main facts, Experimental and Toxicologic Pathology, doi:10.1016/j.etp.2009.08.008

This is a PDF file of an unedited manuscript that has been accepted for publication. As a service to our customers we are providing this early version of the manuscript. The manuscript will undergo copyediting, typesetting, and review of the resulting galley proof before it is published in its final citable form. Please note that during the production process errors may be discovered which could affect the content, and all legal disclaimers that apply to the journal pertain. 
Title: Peroxisomes and Peroxisomal disorders: the main facts.

Author: Marco Fidaleo

Address: Department of Cellular and Developmental Biology, University of Rome "La Sapienza", P.le Aldo Moro 5, 00185 - Rome, Italy

\section{Corresponding Author:}

Marco Fidaleo

Department of Cellular and Developmental Biology, University of Rome "La Sapienza", P.le Aldo Moro 5, 00185 - Rome, Italy

Telephone number: 0039(0)649912317

FAX number: 0039(0)649912351

e-mail: marco.fidaleo@uniroma1.it 


\section{Abstract}

The importance of peroxisomes for human health is highlighted by the number of peroxisomal disorders (PDs), diseases associated to peroxisome biogenesis disorders and peroxisomal enzyme/transporter deficiencies. Currently, many physiological/biosynthetic mechanisms involved in these illnesses have been elucidated, but PDs remain incurable. This review examines the most important aspects concerning peroxisomes (i.e. Peroxisome proliferation, Peroxisome biogenesis, Metabolic functions of mammalian peroxisomes) and presents the most significant trends and advances in the study of peroxisomal disorders.

Key words: Peroxisomes; Peroxisomal biogenesis; Peroxisomal metabolism; Peroxisomal disorders; Peroxisomạl $\beta$-oxidation.

\section{Outline}

1. Introduction

2. Peroxisome proliferation

3. Peroxisomal biogenesis

3.1 Formation of peroxisome membrane (importance of ER)

3.2 Synthesis and import of proteins in peroxisomal matrix

3.3 Synthesis and transport of proteins of peroxisomal membrane

4. Metabolic functions of mammalian peroxisomes

4.1 Peroxisomal $\beta$-oxidation

4.1.1 Peroxisomạl $\beta$-oxidation specific substrates

4.1.2 Activation and transport of fatty acids

4.2 Fatty acid $\alpha$-oxidation 
4.3 Cholesterol biosynthesis

4.4 Metabolism of bile acids

4.5 Role of peroxisomes in biosynthesis of fatty acids

4.6 Synthesis of plasmalogens

4.7 Oxidative stress

5. Peroxisomal disorders

5.1 Peroxisome biogenesis disorders (PBDs)

5.2 Peroxisomal enzyme/transporter deficiencies (PEDs)

6. Conclusion

\section{Abbreviations}

ABC: ATP-binding cassette

$A B C D$ gene: ATP-binding cassette, subfamily D

ACO: acyl-CoA oxidase

ACS: Acyl-CoA synthetase

ALD: Adrenoleukodystrophy

BCFA: Branched-chain fatty acid

CHO: Chinese hamster ovary

CuZnSOD: Copper-zinc superoxide-dismutase

DEHP: Di-(2-ethylhexyl) phthalate

DHA: Docosahexaenoic acid

DHCA: $3 \alpha, 7 \alpha$-dihydroxy-5 $\beta$-cholestanoic acid

DLP-1: Dynamin-Like Protein 1

DRP: Dynamin-related proteins 
ER: Endoplasmic reticulum

FA: Fatty acid

FAT/CD36: fatty acids translocase, CD36

FPP: farnesyl diphosphate

GPx: Glutathione-peroxidase

HMG-CoA: 3-hydroxy-3-methylglutaryl-coenzyme A

IPP: Isopentenyl diphosphate

IRD: Infantile Refsum disease

L-PBE (bifunctional enzyme): peroxisomal L-3-hydroxyacyl-CoA hydratase/L-3-hydroxyacyl-CoA dehydrogenase

MCFA: Medium-chain fatty acid

MnSOD: Manganese superoxide-dismutase

MPPD: mevalonate diphosphate decarboxylase

NALD: Neonatal adrenoleukodystrophy

NBF: Nucleotide-binding fold

NSAID: Non-steroidal anti-inflammatory drug

PBD: Peroxisome biogenesis disorders

PD: Peroxisomal disorders

PED: Peroxisomal enzyme/transporter deficiency

PMP: Peroxisomal membrane proteins

PMVK: Phosphomevalonate kinase

PP: Peroxisome proliferator

PPAR: Peroxisome proliferator-activated receptor

PPP: Pex11-type peroxisome proliferator

pTH: (Human) peroxisomal thiolase 
PTS: Peroxisomal targeting signal

ROS: Rreactive oxygen species

SCFA: Short-chain fatty acid

SCP-2/SCPx: Sterol carrier protein 2/3-ketoacyl-CoA thiolase/Sterol carrier protein X

ThA: Thiolase A

ThB: Thiolase B

THCA: $3 \alpha, 7 \alpha, 12 \alpha$-trihydroxy-5 $\beta$-cholestanoic acid

VLCFA: very long straight-chain fatty acid

X-ALD: X-linked adrenoleukodystrophy

ZS: Zellweger syndrome

ZSD: Zellweger spectrum disorders 


\section{Introduction}

Peroxisomes are organelles found in every eukaryotic cell except mature erythrocytes. They were observed for the first time in mouse renal cells by Rhodin in 1954 and called microbodies. They have a diameter comprised between $0.1-1 \mu \mathrm{m}$, are surrounded by a single-membrane and contain a fine granular matrix. Several enzymes form the granular matrix that are involved in large range of processes. It was shown that peroxisomes are the only organelles whose physiological role differs according to the cell type, tissue and developmental and metabolic state of the organism. $\beta$ oxidation of fatty acids, hydrogen peroxide catabolism and defense against oxidative stresses are the most important conserved functions found in all organisms.

More than 50 enzymes have been discovered in mammalian peroxisomes that participate in various metabolic pathways including $\beta$-oxidation of very long chain fatty acids, prostaglandins, and leukotrienes (Ferdinandusse et al. 2002); biosynthesis of cholesterol, bile acids (in the liver), dolichol, and ether lipids (plasmalogens) (van den Bosch et al. 1992); oxidation of D-amino acids, polyamines, and uric acid (in non-primates) (Subramani et al. 2000; Purdue and Lazarow 2001); and detoxification of xenobiotics, and of reactive oxygen species (ROS) (Schrader and Fahimi, 2006).

In plants, peroxisomes (named glyoxisomes) are mainly involved in the glyoxylate cycle, whereas, in yeasts they are implicated in biosynthesis of lysine and the degradation of methanol and amino acids, as well as in $\beta$-oxidation (Brown and Baker, 2003)

The central role of peroxisomes for human health has been suggested by the discovery of about twenty peroxisomal disorders associated to peroxisomal biogenesis disorders or peroxisomal enzyme/transporter deficiencies. 


\section{Peroxisome proliferation}

The amount of peroxisomes present in a cell results from different processes that can be divided into (a) peroxisome proliferation by division, (b) peroxisome de novo biogenesis, (c) peroxisome inheritance, and (d) peroxisome degradation by pexophagy, an autophagy-related process. The mechanism that regulates all these processes is not well known. Up to date, two classes of proteins, dynamin-related proteins (DRPs), and Pex11-type peroxisome proliferators (PPPs), have been recognized which are strongly involved in controlling peroxisome number and division (Thoms and Erdmann, 2005).

Many structurally diverse chemicals, known as peroxisome proliferators (PPs) are able to induce peroxisome proliferation, i.e. the process that leads to an increase in size and/or number of peroxisomes. PPs comprise drugs used for therapeutic treatment (e.g. fibrates and NSAIDs, nonsteroidal anti-inflammatory drugs), industrial plasticizer di-(2-ethylhexyl) phthalate (DEHP) and environmental pollutants. In addition, physiological stimuli, such as starvation, diabetes mellitus, or high fat diets, induce peroxisome proliferation.

Peroxisome proliferation is particularly evident in the liver of rodents treated with PPs, molecules that exert their biological activity by binding to peroxisome proliferator-activated receptor $\alpha$ (PPAR $\alpha$ ) (Issemann and Green, 1990). PPAR $\alpha$ activation is followed by hepatomegaly due both to hypertrophy and hyperplasia, and by induction of some peroxisomal enzymes, in particular fatty acid $\beta$-oxidation (Gonzalez et al., 1998); furthermore long-term administration of PPs leads to hepatocarcinogensis. This last phenomenon is associated to the accumulation of oxidative stress and cell cycle de-rugalation (Reddy, 2004; Peters et al., 2005).

During PP treatment, hepatic peroxisome content switches from $2 \%$ to $25 \%$ of the cell volume and the liver weight increases from 120\%-200\% (Reddy, 2004). Although the response is most dramatic in rodent liver, PPs affect other tissues such as intestine, adrenal gland, lung, cardiac and skeletal muscle and kidney (Nemali et al., 1988). 
Moreover, different species do not respond in the same way to PPs. Hamsters and rabbits exhibit a modest peroxisome proliferation. In contrast, humans, guinea pigs, dogs and marmosets are either weakly responsive or nonresponsive (Lake and Gray, 1985; Reddy et al., 1986; Foxworthy et al., 1990; Richert et al., 1996).

Finally, a recent study showed that in PPAR ${ }^{-/-}$mice treated with fenofibrate, moderate peroxisomal proliferation is observable which may be imputed to an increase of a type of DRPs, i.e DLP-1 (Dynamin-Like Protein 1) expression and independent to PPAR $\alpha$ (Zhang et al., 2006).

\section{Peroxisomal biogenesis}

Peroxisomal biogenesis has been extensively studied, but many questions remain unanswered. Using mutant yeasts, Chinese hamster ovary (CHO) cells and human fibroblasts, it was shown that the biogenesis involves some proteins called peroxins. Up to date, 32 peroxins have been identified, encoded by Pex genes (Distel et al., 1996; Purdue and Lazarow, 2001; Lazarow 2003; Heiland and Erdmann, 2005). Among these, there are necessary peroxisomal import receptors and peroxisomal membrane proteins (PMPs). Peroxisome generation is a conserved process from yeast to man. In humans, the deficiency of some peroxins involved in peroxisome biogenesis is associated with some serious pathologies i.e. PBD (Peroxisome biogenesis disorder).

The biogenesis of peroxisome could be subdivided in 3 steps: (i) the formation of the peroxisome membrane including the acquisition of PMPs, (ii) the import of peroxisomal matrix proteins, and (iii) the proliferation of peroxisomes (Figure 1). 


\subsection{Formation of peroxisome membrane (importance of ER)}

The biogenesis of peroxisomes has long been matter of debate. A first model, called "growth and division" (Lazarow and Fujiki, 1985; Purdue and Lazarow, 2001) was elaborated. This model was based on the proposed idea of the possibility that peroxisomes are autonomous organelles that have evolved from an endosymbiont, in a manner similar to that of mitochondria and chloroplasts (De Duve, 1996), and also the observation that peroxisomal matrix and membrane proteins are synthesized on free ribosomes and then imported to their destination. On the contrary, Novikoff and Shin, 1964, strongly thought that peroxisomes bud off the endoplasmic reticulum because of the close resemblance between the two structures.

The "growth and division" model elaborated by Lazarow and Fujiki in 1985 has been broadly accepted for many years. This model suggested that new peroxisomes were formed by division and fission of pre-existing ones after the import of newly synthesized proteins from the cytosol. However, this hypothesis of only continuous fission of pre-existing organelles would result in exhaustion of peroxisome membranes. Recent new findings reveal the involvement of ER in the biogenesis of the peroxisomes.

Mutations in genes involved in the import of matrix proteins lead to peroxisomal "ghosts" in which membrane proteins can be found correctly inserted in the lipid bilayer (Purdue and Lazarow, 2001; Eckert and Erdmann, 2003). Exceptions are three mutants of S.cerevisiae, pex3 4 , pex16 1 and pex194, in which peroxisomal membranes are completely absent. These mutants, upon the reintroduction of the corresponding wild-type gene, are able make functional peroxisomes again, suggesting that Pex3p, Pex16p and Pex19p are involved in peroxisome biogenesis. These observations are in contrast with the "growth and division" model proposed by Lazarow and Fujiki (1985) and are in agreement with the hypothesis that the ER plays a role in the origin of the peroxisomal membrane (Titorenko and Rachubinski, 1998; Mullen et al., 2001). This hypothesis 
was also confirmed by Geuze et al., 2003, in mouse dendritic cells, and by Hoepfner et al., 2005, in yeast (reviewed by Kunau, 2005).

\subsection{Synthesis and import of proteins in peroxisomal matrix}

Peroxisomes acquire their matrix proteins by post-translational import from the cytosol. Proteins destined to peroxisome possess a peroxisomal targeting signal (PTS). Actually two types of PTS are found. Many proteins of peroxisomal matrix (about 95\%) possess a PTS1 at the extreme Cterminus, consisting of the tripeptide SKL sequence or species-specific variants (Gould et al., 1989;

Subramani et al., 2000). The PTS2 is found near the N-terminus of only a few matrix proteins and has the consensus sequence $(\mathrm{R} / \mathrm{K})(\mathrm{L} / \mathrm{V} / \mathrm{I}) \mathrm{X}_{5}(\mathrm{H} / \mathrm{Q})(\mathrm{L} / \mathrm{A})$ (Swinkels et al., 1991; Subramani et al., 2000). It was first identified in rat thiolase A and B (Swinkels et al., 1991).

In the cytosol, a PTS1 protein interacts with Pex5p while a PTS2 protein interacts with Pex7p. In turn, Pex $7 p$ binds to Pex14p while Pex $5 p$ binds to Pex13p and Pex14p which are peroxisomal membrane peroxins (Huhse et al., 1998; Shimizu et al., 1999). Translocation may occur through a channel formed by zinc-binding proteins Pex2p, Pex10p, and Pex12p (Huang et al., 2000; Okumoto et al., 2000). Inside the matrix, but close to the membrane, the PTS1 and PTS2 protein cargoes dissociate from their respective receptors. The PTS2 protein-targeting signal is cleaved off (Subramani, 1993). Pex5p and Pex7p are recycled out of the peroxisome, perhaps through the zincbinding proteins or another unidentified export complex, for subsequent rounds of matrix protein binding and import. (Dammai and Subramani, 2001). 


\subsection{Synthesis and transport of proteins of peroxisomal membrane}

Different consensus sequences for membrane protein targeting have been proposed, termed membrane PTS (mPTSs). The most common feature of the few characterized mPTSs consists of a cluster of positively charged, or basic, amino acids (Baerends et al., 2000; Mullen and Trelease, 2000). PMPs are synthesized on free ribosomes in the cytosol. A subset of PMPs, the Type II PMPs, (Sacksteder et al., 2000; Jones et al., 2001; Jones et al., 2004), appears to be directly inserted into the membrane from the cytosol, whereas the Type I PMPs are first localized into a domain on the ER from which a pre-peroxisomal vesicle forms. Each pre-peroxisomal vesicle might fuse with other vesicles or with existing peroxisomes (or could conceivably mature directly), ultimately delivering the membrane proteins to the mature peroxisome (reviewed by Johnson and Olsen, 2001).

\section{Metabolic functions of mammalian peroxisomes}

\subsection{Peroxisomal $\beta$-oxidation}

$\beta$-oxidation is the main pattern of degradation of fatty acids (FAs). In plant and yeast, this process occurs exclusively in peroxisomes, while in other eukaryotes it takes place both in peroxisomes and mitochondria. The major difference between mitochondrial and peroxisomal $\beta$ oxidations is their substrate specificity: in general, mitochondria mainly oxidize short, medium, and most long chain fatty acids, while peroxisomes preferentially oxidize very long straight-chain fatty acids (VLCFAs) (C>20) and branched-chain fatty acids (BCFAs) (Mannaerts and van Veldhoven, 1996). 
The mechanism by which $\beta$-oxidation is performed is identical both in peroxisomes and mitochondria and is made up of 4 steps: (i) dehydrogenation, (ii) hydration, (iii) oxidation and (iv) thiolytic cleavage. After each cycle, fatty acids are shortened of two carbon atoms which are released as acetyl-CoA (Lazarow and De Duve 1976; Rinaldo et al., 2002; Wanders, 2004) (Figure 2).

Dehydrogenation: The first step is the dehydrogenation of the fatty acid CoA conjugate in trans$\Delta^{2}$-enoyl-CoA. The enzyme catalyzes the formation of a double bond between the C-2 and C-3. In mitochondria, this reaction produces $\mathrm{FADH}_{2}$ that carries high-energy electrons to the electron transport chain, helping to drive ATP synthesis. Similarly, in peroxisomal $\beta$-oxidation, FAD is involved as a cofactor, but does not produce $\mathrm{FADH}_{2}$ and does not contribute to ATP production. Instead, hydrogen peroxide is formed, which is then converted to water and oxygen by the enzyme catalase.

Hydration: The next step is the hydration of the bond between C-2 and C-3. The reaction is stereospecific, forming only the L-3-hydroxyacyl-CoA.

Oxidation: In the third step the L-3-hydroxyacyl-CoA is oxidized by $\mathrm{NAD}^{+}$. This converts the hydroxyl group into a keto group forming 3-ketoacyl-CoA and NADH.

Thiolytic cleavage: In the final step a thiol, that comes from a CoA, is inserted between C-2 and C-3 releasing an acetyl-CoA molecule and an acyl-CoA molecule, which is two carbons shorter.

In rodents, two distinct peroxisomal $\beta$-oxidation pathways are found to metabolize either straight-chain fatty acids (Reddy and Mannaerts, 1994; Wanders et al., 2000) or branched-chain fatty acids (Huyghe et al., 2001). Each pathway contains enzymes encoded by different genes. 
Straight-chain fatty acyl-CoAs are catabolized by fatty acyl-CoA oxidase (ACO), peroxisomal L-3hydroxyacyl-CoA hydratase/L-3-hydroxyacyl-CoA dehydrogenase (bifunctional enzyme: L-PBE) and peroxisomal 3-ketoacyl-CoA thiolase (thiolase).

The enzymes involved in the branched-chain fatty acids pathway include branched-chain fatty acyl-CoA oxidase, peroxisomal D-3-hydroxyacyl-CoA hydratase/D-3-hydroxyacyl-CoA dehydrogenase (bifunctional enzyme: D-PBE) and sterol carrier protein 2/3-ketoacyl-CoA thiolase (SCP-2/thiolase) also named sterol carrier protein x (SCPx).

Different names have been given to this enzyme, including D-bifunctional protein (DBP), Dperoxisomal bifunctional enzyme (D-PBE), multifunctional enzyme II (MFEII), and multifunctional protein 2 (MFP2).

The last step for straight-chain fatty acids peroxisomal $\beta$-oxidation in rodents is catalyzed by two enzymes encoded by two different genes: thiolase A $(T h A)$ and thiolase B $(T h B)$. The hepatic ThB gene expression is strongly regulated by peroxisome proliferators (PPs), while $T h A$ is not affected by PP treatment.

Human peroxisomes contain two peroxisomal thiolases, i.e. pTH1 and pTH2. Human pTH1 is similar to the rodent clofibrate-inducible thiolase (Miyazawa et al., 1980), whereas pTH2 is very similar to the $58 \mathrm{kDa}$ sterol carrier protein $\mathrm{x}(\mathrm{SCPx})$, with both thiolase activity and a sterol carrier protein domain (Seedorf et al., 1994). It is clear now that pTH2 (SCPx) plays a key role in the oxidation of 2-methyl branched-chain fatty acids, whereas pTH1 and pTH2 are both involved in C26:0 oxidation.

Once the fatty acid chains are reduced in length in the peroxisome, they are conjugated to carnitine and leave the peroxisome to be transported into mitochondria for further oxidation to acetyl-CoA. 


\subsubsection{Peroxisomal $\beta$-oxidation specific substrates}

Short- and medium-chain fatty acid (SCFAs and MCFAs) derived from diet, including palmitic (C16:0), oleic (C18:1), linoleic (C18:2) and linolenic (C18:3) acid are exclusively degraded in the mitochondria, whereas peroxisomes catalyze the $\beta$-oxidation of the VLCFA such as hexacosanoic acid (C26:0), branched-chain fatty acids and other molecules as pristanic acid, di- and

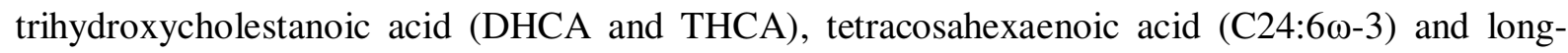
chain dicarboxylic acids (Reddy and Hashimoto, 2001; Ferdinandusse et al., 2004). VLCFAs are in part derived from dietary sources but also formed by chain-elongation of long-chain fatty acids. In humans, most of the $\mathrm{C} 26: 0$ is produced by chain elongation.

Moreover, although mitochondrial $\beta$-oxidation allows a complete degradation of fatty acid, peroxisomal $\beta$-oxidation is incomplete and produces medium chain acyl-CoA, (octanoyl-CoA), propionyl-CoA and acetyl-CoA. (Ferdinandusse et al., 1999; Reddy and Hashimoto, 2001). Finally, acetyl-CoA may be recycled into another $\beta$-oxidation cycle or exported out of peroxisome, while octanoyl-CoA is exported into the mitochondria to be further oxidized.

\subsubsection{Activation and transport of fatty acids}

Fatty acids which undergo oxidation are derived from food or from fatty acids stored in adipocytes. The breakdown of this fat is known as lipolysis. Moreover, another source of fatty acids comes from the synthesis or degradation of lipid complexes within lysosomes.

Fatty acids are imported in cell by several plasma membrane proteins, e.g. fatty acid translocase (FAT/CD36) (Bonen et al. 1999).

In the cytosol, fatty acids are quickly activated and coupled to CoA by the acyl-CoA synthetases (ACSs), which are specific for each type of fatty acid. On the contrary, acyl-CoA may be 
hydrolyzed by Acyl-CoA thioesterases in free fatty acid and CoA-SH (Hunt et al., 2006). This mechanism regulates the fine balance of free fatty acids and acyl-CoA in the cell (Watkins, 1998).

Short and medium-chain fatty acids may entry by diffusion in mitochondria while transfer of long fatty acids across the inner mitochondrial membrane involves carnitine (Kerner and Hoppel, 2000).

In peroxisomes, the activated fatty acids are imported by the ATP-binding cassette transporters (ABC transporters) of peroxisome membrane. These are transmembrane proteins that function in the transport of a wide variety of substrates across extra- and intracellular membranes, including metabolic products, lipids and sterols, and drugs. Proteins are classified as ABC transporters based on the sequence and organization of their ATP-binding domain(s), also known as nucleotidebinding folds (NBFs).

Peroxisomal $\beta$-oxidation products (acetyl-CoA, octanoyl-CoA) are exported to cytosol (Ferdinandusse et al., 1999; Reddy et Hashimoto, 2001; Lamhonwah et al., 2005).

\subsection{Fatty acid $\boldsymbol{\alpha}$-oxidation}

Branched-chain fatty acids, in particular phytanic acid, which have a methyl group at the 3position cannot be $\beta$-oxidized because the 3-methyl group blocks $\beta$-oxidation. These fatty acids, thanks to $\alpha$-oxidation, which involves the oxidative decarboxylation of the 3 -methyl fatty acid to produce the 2-methyl fatty acid, can be subsequently degraded by $\beta$-oxidation. In higher eukaryotes, including humans, peroxisomes are the sole site of $\alpha$-oxidation.

The enzymatic machinery required for fatty acid $\alpha$-oxidation has been resolved in recent years and requires the concerted action of 3 enzymes including: (i) phytanoyl-CoA hydroxylase, (ii) 2hydroxyphytanoyl-CoA lyase and (iii) pristanal dehydrogenase (reviewed by Wierzbicki, 2007). 


\subsection{Cholesterol biosynthesis}

Peroxisomes, mitochondria and ER are involved in cholesterol biosynthesis. As summarized in Figure 3, the initial conversion of acetyl-CoA to 3-hydroxy-3-methylglutaryl-coenzyme A (HMGCoA) occurs in peroxisomes, ER and mitochondria (Thompson et al., 1990; Hovik et al., 1991). Further conversion of HMG-CoA to mevalonate might take place both in the ER and peroxisomes, although recent studies show contradictory results (Kovacs et al., 2007). However, the following conversion of mevalonate to farnesyl diphosphate (FPP) occurs predominantly in the peroxisomes. Further metabolism of FPP to squalene proceeds exclusively in the ER, and the final conversion of lanosterol to cholesterol occurs in the ER and may also be localized to peroxisomes. Although some studies have indicated that many of the enzymes involved in these reactions are localized to the peroxisomes, the mechanisms for targeting to peroxisomes have been demonstrated at first for phosphomevalonate kinase (PMVK) and isopentenyl diphosphate (IPP) isomerase (Paton et al., 1997; Olivier et al., 1999), and subsequently for acetoacetyl-CoA thiolase, HMG-CoA synthase, mevalonate diphosphate decarboxylase (MPPD), and FPP synthase.

The HMG-CoA reductase catalyzes the conversion of HMG-CoA into mevalonate, which is the rate-limiting step of the cholesterol biosynthetic pathway. Although HMG-CoA reductase is lacking of peroxisomal targeting information, a number of studies indicate that it is located not only in the ER but also in peroxisomes (Keller et al., 1985; Keller, 1986; Engfelt et al., 1997; reviewed by Olivier et al., 2000 and Kovacs et al., 2007).

\subsection{Metabolism of bile acids}

Bile acids are the main degradation products of cholesterol, and many enzymes involved in this process are located in peroxisomes (Pedersen, 1993). 


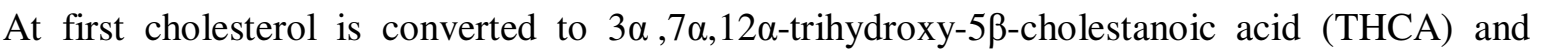
$3 \alpha, 7 \alpha$-dihydroxy-5 $\beta$-cholestanoic acid (DHCA), precursors, respectively, of bile acid cholate and chenodeoxycholate (Vlahcevic et al., 1999; Setchell and O'Connell, 2001). Subsequently, after activation and transport to peroxisomes, the chain shortening of the methyl-branched side chain of THCA and DHCA is made by $\beta$-oxidation (Wanders et al., 2001).

The bile acids are conjugated to the amino acid glycine or taurine by bile acyl-CoA amino-acid $N$-acyltransferase in the hepatocyte and are stored in the gallbladder (Vlahcevic et al., 1999; Setchell and O'Connell, 2001).

\subsection{Role of peroxisomes in biosynthesis of fatty acids}

Peroxisomes play a very important role also in the synthesis of very long-chain fatty acids, such as docosahexaenoic acid (C22:6n-3, DHA).

DHA is derived from the dietary essential fatty acid linolenic acid (C18:3n-3), via a series of alternating desaturation and elongation steps (Brenner, 1971; Sprecher, 1992).

Of very important interest is the last step of the synthesis of DHA, i.e. the conversion of C22:5n3 to DHA. C22:5n-3 is elongated to C24:5n-3, desaturated to C24:6n-3 in microsomes, and then retroconverted to $\mathrm{C} 22: 6 n-3$ in peroxisomes ( $\mathrm{Su}$ et al., 2001).

\subsection{Synthesis of plasmalogens}

Plasmalogens are ether lipids, with an ether group at the first carbon position of the glycerol. Two enzyme involved in their synthesis, acyldihydroxyacetone phosphate acetyl transferase and dihydroxyacetone phosphate acetyl transferase, have been isolated in peroxisomes and ER. Plasmalogen is the most abundant phospholipid in myelin. Absence of plasmalogens causes 
profound abnormalities in the myelination of nerve cells, which is one of the reasons that many peroxisomal disorders lead to neurological disease. (Heymans et al., 1983).

\subsection{Oxidative stress}

The respiratory pathway in peroxisomes, in which electrons removed from various metabolites reduce $\mathrm{O}_{2}$ to $\mathrm{H}_{2} \mathrm{O}_{2}$ (which is further reduced to $\mathrm{H}_{2} \mathrm{O}$ ), was first described by De Duve and Baudhuin (1966). This process is not associated with oxidative phosphorylation, and does not lead to the production of ATP. Free energy is released in the form of heat.

In addition to the generation of ROS, peroxisomes contain several ROS-metabolizing enzymes. These observations have supported the notion that these ubiquitous organelles play a key role both in the production and scavenging of ROS, in particular $\mathrm{H}_{2} \mathrm{O}_{2}$, in the cell.

ROS include radical species (containing free, i.e. unpaired, electrons), such as the superoxide anion $\left(\mathrm{O}_{2} \cdot{ }^{-}\right)$, which is formed through one-electron reduction of $\mathrm{O}_{2}\left(\mathrm{O}_{2}+\mathrm{e}^{-} \rightarrow \mathrm{O}_{2} \cdot{ }^{-}\right)$. Hydrogen peroxide $\left(\mathrm{H}_{2} \mathrm{O}_{2}\right)$ is also considered a ROS, although it has no unpaired electrons, and thus it is not a radical. It can, for example, be formed by the dismutation reaction of $\mathrm{O}_{2} \cdot{ }^{-}$(catalyzed by superoxide dismutases) via the hydroperoxyl radical $\left(\mathrm{O}_{2} \cdot{ }^{-}+\mathrm{H}^{+} \rightarrow \mathrm{HO}_{2} \cdot{ }^{-} ; 2 \mathrm{HO}_{2} \cdot{ }^{-} \rightarrow \mathrm{H}_{2} \mathrm{O}_{2}+\mathrm{O}_{2}\right)$. Probably the most highly reactive and toxic form of oxygen, the hydroxyl radical $(\cdot \mathrm{OH})$, can be formed by the metal ion (e. g., iron or copper)-catalyzed decomposition of $\mathrm{H}_{2} \mathrm{O}_{2} \quad\left(\mathrm{H}_{2} \mathrm{O}_{2}+\right.$ $\left.\mathrm{O}_{2} \cdot{ }^{-} \rightarrow \mathrm{O}_{2}+\mathrm{OH}^{-}+\cdot \mathrm{OH}\right)$

High levels of ROS exert a toxic effect on biomolecules such as DNA, proteins, and lipids (e.g., non-enzymatic lipoperoxidation), thus leading to i) the accumulation of oxidative damage in diverse cellular compartments, ii) the deregulation of redox-sensitive metabolic and signaling pathways, and iii) pathological events. 
Several peroxisome enzymes, such as $\beta$-oxidation system, urate oxidase, xanthine oxidase, pipecolic acid oxidase, sarcosine oxidase, L- $\alpha$-hydroxy acid oxidase, polyamine oxidase, lead $\mathrm{H}_{2} \mathrm{O}_{2}$ production (Barroso et al., 1999).

$\mathrm{H}_{2} \mathrm{O}_{2}$ is decomposed by catalase and glutathione-peroxidase (GPx) (which is a primary cytosolic enzyme, also found in peroxisome) or converted to hydroxyl radicals (.OH). In addition to degrading the ROS, peroxisomes harbor several other powerful defense mechanisms and antioxidant enzymes. Superoxide anions $\left(\mathrm{O}_{2} \cdot{ }^{-}\right)$generated by peroxisomal oxidases are scavenged by both manganese superoxide-dismutase (MnSOD) and copper-zinc superoxide-dismutase (CuZnSOD).

Other enzymes are able to produce ROS: i.e. nitric oxide synthase, which generates nitric oxide $(\cdot \mathrm{NO})$, a molecule with significant signaling functions in animals and plants. In particular, in animal cells, an inducible form of the enzyme (iNOS) is expressed under pathological conditions which can cause severe tissue injury (Stolz et al., 2002).

Nitric oxide synthase (NOS) catalyses the oxidation of L-arginine (L-Arg) to nitric oxide ( $\cdot \mathrm{NO})$. $\cdot \mathrm{NO}$ can react with $\mathrm{O}_{2} \cdot{ }^{-}$radicals to form peroxynitrite $\left(\mathrm{ONOO}^{-}\right)$, a powerful oxidant.

$\mathrm{H}_{2} \mathrm{O}_{2}$ and $\cdot \mathrm{NO}$ can cross the peroxisomal membrane and act in cellular signaling (reviewed by Schrader and Fahimi, 2006).

\section{Peroxisomal disorders}

In the early 1980s peroxisomal disorders (PDs) were first being recognized and described. Currently, about 16 different types of peroxisomal disorders are known (Table 1). The cause of these disorders may be associated to peroxisome biogenesis disorders (PBDs) or peroxisomal enzyme/transporter deficiencies (PEDs). 
To further clarify the defective mechanisms linked to these diseases, knockout mouse models have been produced. As reported in Table 2, the silencing of genes involved in peroxisomal biogenesis or peroxisomal enzymes in mice can cause disease conditions with a large similarity to those affecting humans. On the other hand, the mutation of some genes coding for peroxisomal proteins produces no significant peroxisomal dysfunction nor diseases similar to those in humans. Knockout mouse models for PPAR $\alpha$ (or its isotypes, i.e. PPAR $\delta$ and PPAR $\gamma$ ) are not listed in the table because these mutations, though determining some dysfunctions in the organism, do not cause peroxisomal diseases in mice.

\subsection{Peroxisome biogenesis disorders (PBDs)}

The PBD group comprises Zellweger spectrum disorders, ZSDs (which include Zellweger syndrome, ZS, neonatal adrenoleukodystrophy, NALD, and infantile Refsum disease, IRD), and rhizomelic chondrodysplasia punctata (RCDP) type 1. Common to ZSDs are liver disease, variable neurodevelopmental delay, retinopathy, and perceptive deafness with onset in the first months of life. In addition, patients with ZS are severely hypotonic and weak from birth and have distinct facial features, peri-articular calcifications, severe brain dysfunction associated with neuronal migration disorders and die before 1 year of age. The ZS, also known as cerebro-hepato-renal syndrome, is characterized by the absence of peroxisomes in the cells of the liver, kidney, and brain (Goldfischer et al., 1973).

PBDs are associated, at molecular level, with a mutation of some peroxins indispensable for the biogenesis of peroxisome or of some peroxisomal carrier proteins. Many studies have indicated that the mutation of Pex7, which encodes the receptor for PTS2 proteins, results in RCDP type I, while the ZSDs derive from the possible mutation in 12 different genes $(P e x 1,2,3,5,6,10,12,13,14$, 16, 19, 26) (Gould and Valle, 2000; Shimozawa et al., 2004; Wanders and Waterham, 2005). 
The biochemical anomalies correlated to these diseases present an accumulation of VLCFAs (C24:0, C25:0, C26:0), THCA and DHCA (from bile acids synthesis), branched-chain fatty acid (pristanic and phytanic acid) and a decrease in synthesis of plasmalogens and DHA (Jansen et al, 2001)

\subsection{Peroxisomal enzyme/transporter deficiencies (PEDs)}

PEDs are disorders in which the peroxisome is intact and functioning, but a defect in one enzyme process causes the primary biochemical abnormality. Although PEDs involve the loss of even a single peroxisome function, these diseases are severe and can closely mimic the PBDs (Wanders and Waterham, 2005).

PEDs may affect different peroxisomal pathways. The most known peroxisomal diseases involve ether phospholipid synthesis (Rhizomelic chondrodysplasia punctata Type 2 due to DHAPAT deficiency), peroxisomal $\beta$-oxidation (Rhizomelic chondrodysplasia punctata Type 3 due to alkylDHAP synthase, X-linked adrenoleukodystrophy, acyl-CoA oxidase deficiency, D-bifunctional protein deficiency, 2-MethylacylCoA racemase deficiency, sterol carrier protein X deficiency), peroxisomal $\alpha$-oxidation (Refsum disease due to phytanoyl-CoA due to hydroxylase deficiency), glyoxylate detoxification (determining hyperoxaluria Type 1) and $\mathrm{H}_{2} \mathrm{O}_{2}$-metabolism (Acatalasaemia) (Wanders and Waterham, 2005).

Diseases which involve alterations in peroxisomal $\beta$-oxidation system cause an accumulation in VLCFAs in the blood flux (Gärtner, 2000).

With the exception of X-linked adrenoleukodystrophy (X-ALD), all of these disorders are autosomal recessive.

$\mathrm{X}-\mathrm{ALD}$ is characterized by a defect in the ABCD1 gene (ATP-binding cassette, subfamily D, member 1 gene) which encodes for a protein that transfers fatty acids into peroxisomes, where they undergo $\beta$-oxidation. The ABCD1 dysfunctional gene leads to the accumulation of VLCFA. It is 
still unknown how the transporter affects the function of the fatty acid enzyme and, for that matter, how high levels of very long chain fatty acids cause the loss of myelin on nerve fibers (Shani and Valle, 1996). The prevalence of X-linked adrenoleukodystrophy is approximately 1 in 20,000 individuals. This condition occurs with a similar frequency in all populations.

Up to date, there is no cure for X-ALD. Some dietary treatments, for example, Lorenzo's oil (4:1 mixture of glycerol trioleate and glycerol trierucate, the triglyceride forms of oleic and erucic acid) in combination with a diet low in VLCFA, have been used with limited success, especially before disease symptoms appear. A recent study by Moser et al (2005) shows positive long-term results with this approach.

Bone marrow transplantation has been proven to help adrenoleukodystrophy (ALD) patients who are either pre-symptomatic or exhibiting mild symptoms early in the course of the disease. The therapy with the hypolipidemic drug Lovastatin seems to normalize VLCFAs in the plasma of patients with X-ALD and increase in peroxisome, ABCD1 and Pex11 $\alpha$ (Singh et al., 1998).

Finally, treatment is useful only to alleviate the symptoms but not to cure the disease.

\section{Conclusion}

A wide range of different genetic pathologies can lead to inefficiency of peroxisomal functions. In some cases the resulting diseases have comparable symptoms but, since they are determined by deficiency of different genes, a common treatment is not possible. There have been many efforts to produce biological systems, such as cell and mouse models, that could be helpful in investigating disease complications and evaluating possible alternative treatments. For example, Gueugnon et al., 2007, showed that dehydroepiandrosterone (the most abundant steroid in human) up-regulates the adrenoleukodystrophy-related gene (ABCD2), the closest homolog of $\mathrm{ABCD} 1$, which could be considered a potential therapeutic target for ALD-X, as functional redundancy has been demonstrated between the two proteins. Another suggested therapeutic strategy for ALD-X is 
autotransplantation of genetically corrected hematopoietic stem cells using a lentiviral vector, with the aim of replacing the endogenous brain microglia from patients. Yet another approach is using stereotactic injections of viral vectors for directly targeting the ALD gene into brain glial cells (Cartier, 2001; Cartier and Aubourg, 2008).

New pathologies linked to peroxisome defaults are frequently discovered. Michelakakis et al., 2004, reported the case of the first patient who presented Leber congenital amaurosis that was subsequently demonstrated to be a PEX1 peroxisome biogenesis defect.

Currently, early diagnosis remains the best way to alleviate, when possible, disease pains. Dietary therapy with Lorenzo's Oil has been shown to have a preventive effect by X-ALD in asymptomatic boys with normal brain magnetic resonance imaging (Moser, 2006).

Analysis of peroxisomal $\beta$-oxidation and plasmalogen synthesis on cultured cells derived from chorionic villi or amniotic fluid cells are the two most common practices for prenatal testing in the case of families at risk (Steinberg et al. 2006); while postnatal testing is carried out on blood (Shimozawa, 2007)

Difficulties of early diagnosis are due to the fact that obligate carriers, such as those for ZS and RCDP disorders, do not express partial defects. Thus, although prenatal diagnosis is possible, prenatal counseling for unaware couples is not done habitually.

As discussed previously, a definitive cure for these peroxisomal diseases is not yet possible, but in the author's opinion, as regards X-ALD (and the main phenotypes of this, such as the childhood cerebral form, CCALD, and the adrenomyeloneuropathy, AMN) three different therapeutic approaches must be mentioned which could strongly block disease progression and offer good perspective for the future. A study done by Genin et al., 2009, shows that pharmacological treatment with a thyroid hormone homolog, CGS 23425 (which does not show the typical side effects on heart, bones and muscles of thyroid hormones), can up regulate ABCD2 in different models, compensating ABCD1 lacking. Currently, this study is in the preclinical stage, but results are encouraging. Two other therapeutic approaches have provided enthusiastic results. As 
mentioned, Cartier and Aubourg, 2008, propose a transplantation of autologous hematopoietic stem cells genetically modified to express the missing protein, thus avoiding problems associated with allogeneic hematopoietic stem-cell transplantation. This strategy has now reached the stage of phase I/II clinical trials to assess safety and potential efficacy. A second study, in an advanced stage, reports a successful cord blood transplantation using a reduced-intensity conditioning regimen to reduce regimen-related toxicity and transplant-associated morbidity and mortality for advanced childhood-onset cerebral adrenoleukodystrophy. The treatment was well tolerated, stopped disease progression and contributed to a good neuropsychological outcome (Awaya et al., 2009).

In recent times, researchers have begun to understand more about peroxisomal disorders, but the only aid that can currently be given to patients is to slow down the beginning symptoms. Unfortunately, the phenotypes associated with peroxisomal defects are not clear and treatment may be ineffective when disease symptoms arise. Furthermore, more and more diseases have only recently been found to be related to peroxisomal disorders.

\section{Acknowledgments}

I wish to thank Pr. Claudia Sartori for her critical reading of the manuscript.

\section{Bibliography}

Awaya T, Kato T, Niwa A, Hiramatsu H, Umeda K, Watanabe KI, Shibata M, Yamanaka Y, Maruya E, Saji H, Nakahata T, Adachi S (2009) Successful cord blood transplantation using a reduced-intensity conditioning regimen for advanced childhood-onset cerebral adrenoleukodystrophy. Pediatr Transplant. [Epub ahead of print]

Baerends RJS, Faber KN, Kiel JAKW, van der Klei IJ, Harder W, Veenhuis M (2000) Sorting and function of peroxisomal membrane proteins. FEMS Microbiol Rev 24: 291-301 
Baes M, Gressens P, Baumgart E, Carmeliet P, Casteels M, Fransen M, Evrard P, Fahimi D, Declercq PE, Collen D, van Veldhoven PP, Mannaerts GP (1997) A mouse model for Zellweger syndrome., Nat Genet;17(1):49-57

Baes M, Huyghe S, Carmeliet P, Declercq PE, Collen D, Mannaerts GP, Van Veldhoven PP (2000) Inactivation of the peroxisomal multifunctional protein-2 in mice impedes the degradation of not only 2-methyl-branched fatty acids and bile acid intermediates but also of very long chain fatty acids., J Biol Chem;275(21):16329-36

Barroso JB, Corpas FJ, Carreras A, Sandalio LM, Valderrama R, Palma JM, Lupiáñez JA, del Río LA. (1999) Localization of nitric-oxide synthase in plant peroxisomes. J Biol Chem 274(51):3672936733.

Bjorkman J, Tonks I, Maxwell MA, Paterson C, Kay GF, Crane DI (2002) Conditional inactivation of the peroxisome biogenesis Pex13 gene by Cre-loxP excision., Genesis;32(2):179-80

Bonen A Miskovic D Kiens B (1999) Fatty acid transporters (FABPpm, FAT, FATP) in human muscle. Can J Appl Physiol 24(6):515-523

Brenner RR (1971) The desaturation step in the animal biosynthesis of polyunsaturated fatty acids. Lipids 6, 567-575

Brites P, Motley AM, Gressens P, Mooyer PA, Ploegaert I, Everts V, Evrard P, Carmeliet P, Dewerchin M, Schoonjans L, Duran M, Waterham HR, Wanders RJ, Baes M (2003) Impaired 
neuronal migration and endochondral ossification in Pex7 knockout mice: a model for rhizomelic chondrodysplasia punctata., Hum Mol Genet; 12(18):2255-67

Brown LA, Baker A (2003) Peroxisome biogenesis and the role of protein import. J Cell Mol Med Annu Rev Physiol 64:477-502.

Cartier N, Aubourg P (2008) Hematopoietic stem cell gene therapy in Hurler syndrome, globoid cell leukodystrophy, metachromatic leukodystrophy and X-adrenoleukodystrophy. Curr Opin Mol Ther. 10(5):471-8.

Cartier N (2001) Gene therapy strategies for X-linked adrenoleukodystrophy. Curr Opin Mol Ther. 3(4):357-61.

Chevillard G, Clemencet MC, Latruffe N, Nicolas-Frances V (2004) Targeted disruption of the peroxisomal thiolase B gene in mouse: a new model to study disorders related to peroxisomal lipid metabolism., Biochimie;86(11):849-56

Dammai V, Subramani S (2001) The human peroxisomal targeting signal receptor, Pex5p, is translocated into the peroxisomal matrix and recycled to the cytosol. Cell 105:187-196

De Duve C, Baudhuin P, (1966) Peroxisomes (microbodies and related particles). Physiol Rev 46(2):323-57.

DeDuve C (1996) The birth of complex cells. Sci. Am 274:50-57. 
Distel B, Erdmann R, Gould SJ, Blobel G, Crane DI, Cregg JM, Dodt G, Fujiki Y, Goodman JM, Just WW, Kiel JA, Kunau WH, Lazarow PB, Mannaerts GP, Moser HW, Osumi T, Rachubinski RA, Roscher A, Subramani S, Tabak HF, Tsukamoto T, Valle D, van der Klei I, van Veldhoven PP, Veenhuis M (1996) A unified nomenclature for peroxisome biogenesis factors. J Cell Biol 135(1):13.

Eckert JH, Erdmann R (2003) Peroxisome biogenesis. Rev Physiol Biochem Pharmacol 147:75121

Engfelt WH, Shackelford JE, Aboushadi N, Jessani N, Masuda K, Paton VG, Keller GA, Krisans SK (1997) Characterization of UT2 cells. The induction of peroxisomal 3-hydroxy-3methylglutaryl-coenzyme A reductase. J. Biol. Chem. 272:24579-24587.

Fan CY, Pan J, Chu R, Lee D, Kluckman KD, Usuda N, Singh I, Yeldandi AV, Rao MS, Maeda N, Reddy JK (1996) Hepatocellular and hepatic peroxisomal alterations in mice with a disrupted peroxisomal fatty acyl-coenzyme A oxidase gene., J Biol Chem;271(40):24698-710

Faust PL, Hatten ME (1997) Targeted deletion of the PEX2 peroxisome assembly gene in mice provides a model for Zellweger syndrome, a human neuronal migration disorder., J Cell Biol; 139(5):1293-305

Ferdinandusse S, Denis S, Van Roermund CW, Wanders RJ, Dacremont G (2004) Identification of the peroxisomal beta-oxidation enzymes involved in the degradation of long-chain dicarboxylic acids. J Lipid Res 45(6):1104-11. 
Ferdinandusse S, Meissner T, Wanders RJ, Mayatepek E (2002) Identification of the peroxisomal beta-oxidation enzymes involved in the degradation of leukotrienes. Biochem Biophys Res Commun 293:269-273.

Ferdinandusse S, Mulders J, IJlst L, Denis S, Dacremont G, Waterham HR, Wanders RJ (1999) Molecular cloning and expression of human carnitine octanoyltransferase: evidence for its role in the peroxisomal beta-oxidation of branched-chain fatty acids. Biochem Biophys Res Commun 263(1):213-8

Ferdinandusse S, Zomer AW, Komen JC, van den Brink CE, Thanos M, Hamers FP, Wanders RJ, van der Saag PT, Poll-The BT, Brites P (2008) Ataxia with loss of Purkinje cells in a mouse model for Refsum disease., Proc Natl Acad Sci U S A;105(46):17712-7

Forss-Petter S, Werner H, Berger J, Lassmann H, Molzer B, Schwab MH, Bernheimer H, Zimmermann F, Nave KA (1997) Targeted inactivation of the X-linked adrenoleukodystrophy gene in mice., J Neurosci Res;50(5):829-43

Foxworthy PS, White SL, Hoover DM, Eacho PI (1990) Effect of ciprofibrate, bezafibrate, and LY171883 on peroxisomal beta-oxidation in cultured rat, dog, and rhesus monkey hepatocytes. Toxicol Appl Pharmacol 104(3):386-394.

Gärtner J (2000) Disorders related to peroxisomal membranes. J Inherit Metab Dis. 23(3):264-272.

Genin EC, Gondcaille C, Trompier D, Savary S (2009) Induction of the adrenoleukodystrophyrelated gene (ABCD2) by thyromimetics. J Steroid Biochem Mol Biol. 116(1-2):37-43. Epub 2009 May 3 
Geuze HJ, Murk JL, Stroobants AK, Griffith JM, Kleijmeer MJ, Koster AJ, Verkleij AJ, Distel B, Tabak HF (2003) Involvement of the endoplasmic reticulum in peroxisome formation. Mol Biol Cell14(7):2900-2907.

Goldfischer S, Moore CL, Johnson AB, Spiro AJ, Valsamis MP, Wisniewski HK, Ritch RH, Norton WT, Rapin I, Gartner LM (1973) Peroxisomal and mitochondrial defects in the cerebro-hepatorenal syndrome. Science 182(107):62-64.

Gonzalez FJ, Peters JM, Cattley RC (1998), Mechanism of action of the nongenotoxic peroxisome proliferators: role of the peroxisome proliferator-activator receptor alpha. J Natl Cancer Inst 90(22):1702-1709

Gould SJ, Keller GA, Hosken N, Wilkinson J, Subramani S (1989) A conserved tripeptide sorts proteins to peroxisomes. J Cell Biol 108:1657-1664

Gould SJ, Valle D (2000) Peroxisome biogenesis disorders: genetics and cell biology. Trends Genet $16(8): 340-345$.

Gueugnon F, Gondcaille C, Leclercq S, Bellenger J, Bellenger S, Narce M, Pineau T, Bonnetain F, Savary S (2007) Dehydroepiandrosterone up-regulates the Adrenoleukodystrophy-related gene (ABCD2) independently of PPARalpha in rodents. Biochimie. 89(11):1312-21.

Heiland I., Erdmann R. (2005), Biogenesis of peroxisomes. Topogenesis of the peroxisomal membrane and matrix proteins. Febs J 272(10):2362-2372. 
Heinzer AK, Watkins PA, Lu JF, Kemp S, Moser AB, Li YY, Mihalik S, Powers JM, Smith KD (2003) A very long-chain acyl-CoA synthetase-deficient mouse and its relevance to X-linked adrenoleukodystrophy. Hum Mol Genet;12(10):1145-54.

Heymans HS, Schutgens RB, Tan R, van den Bosch H, Borst P (1983) Severe plasmalogen deficiency in tissues of infants without peroxisomes (Zellweger syndrome) Nature 306(5938):6970).

Ho YS, Xiong Y, Ma W, Spector A, Ho DS (2004) Mice lacking catalase develop normally but show differential sensitivity to oxidant tissue injury., J Biol Chem;279(31):32804-12

Hoepfner D, Schildknegt D, Braakman I, Philippsen P, Tabak HF (2005) Contribution of the endoplasmic reticulum to peroxisome formation. Cell 122:85-95.

Holroyd C and Erdmann R (2001) Protein translocation machineries of peroxisomes. FEBS Lett. 501(1):6-10.

Hovik R, Brodal B, Bartlett K, Osmundsen H (1991) Metabolism of acetyl-CoA by isolated peroxisomal fractions: formation of acetate and acetoacetyl-CoA. J. Lipid Res. 32:993-999

Huang Y, Ito R, Miura S, Hashimoto T, Ito M. (2000) A missense mutation in the RING finger motif of PEX2 protein disturbs the import of peroxisome targeting signal 1 (PTS1)-containing protein but not the PTS2-containing protein. Biochem Biophys Res Commun 270(3):717-721. 
Huhse B, Rehling P, Albertini M, Blank L, Meller K, Kunau WH (1998) Pex17p of Saccharomyces cerevisiae is a novel peroxin and component of the peroxisomal protein translocation machinery. $\mathrm{J}$ Cell Biol 140(1):49-60.

Hulshagen L, Krysko O, Bottelbergs A, Huyghe S, Klein R, Van Veldhoven PP, De Deyn PP, D'Hooge R, Hartmann D, Baes M (2008) Absence of functional peroxisomes from mouse CNS causes dysmyelination and axon degeneration., J Neurosci; 28(15):4015-27

Hunt MC, Rautanen A, Westin MA, Svensson LT, Alexson SE (2006) Analysis of the mouse and human acyl-CoA thioesterase (ACOT) gene clusters shows that convergent, functional evolution results in a reduced number of human peroxisomal ACOTs. FASEB J. 20(11):1855-1864

Huyghe S, Casteels M, Janssen A, Meulders L, Mannaerts GP, Declercq PE, van Veldhoven PP, Baes M (2001) Prenatal and postnatal development of peroxisomal lipid-metabolizing pathways in mouse. Biochem J 353:673-680.

Issemann I, Green S (1990) Activation of a member of the steroid hormone receptor superfamily by peroxisome proliferators. Nature 347(6294):645-650.

Jansen GA, van den Brink DM, Ofman R, Draghici O, Dacremont G, Wanders RJ (2001) Identification of pristanal dehydrogenase activity in peroxisomes: conclusive evidence that the complete phytanic acid alpha-oxidation pathway is localized in peroxisomes. Biochem Biophys Res Commun 283(3):674-679. 
Jia Y, Qi C, Zhang Z, Hashimoto T, Rao MS, Huyghe S, Suzuki Y, Van Veldhoven PP, Baes M, Reddy JK (2003) Overexpression of peroxisome proliferator-activated receptor-alpha (PPARalpha)regulated genes in liver in the absence of peroxisome proliferation in mice deficient in both L- and D-forms of enoyl-CoA hydratase/dehydrogenase enzymes of peroxisomal beta-oxidation system. J Biol Chem; 278(47):47232-9.

Johnson TL, Olsen LJ (2001) Building New Models for Peroxisome Biogenesis, Plant Physiol. 127:731-739

Jones JM, Morrell JC, Gould SJ (2001) Multiple distinct targeting signals in integral peroxisomal membrane proteins. J Cell Biol, 153(6):1141-1150.

Jones JM, Morrell JC, Gould SJ (2004) PEX19 is a predominantly cytosolic chaperone and import receptor for class 1 peroxisomal membrane proteins. J Cell Biol 164(1):57-67.

Keller GA, Barton MC, Shapiro DJ, Singer SJ (1985) 3-Hydroxy-3methyl-glutaryl-coenzyme A reductase is present in peroxisomes in normal rat liver cells. Proc. Natl. Acad. Aci. USA. 82:770774.

Keller GA, Pazirandeh M, Krisans SK (1986) 3-Hydroxy-3methyl-glutaryl-coenzyme A reductase localization in rat liver peroxisomes and microsomes of control and cholestyramine treated animals: quantitative biochemical and immunoelectron microscopical analysis. J. Cell Biol. 103:875-886.

Kerner J, Hoppel C (2000) Fatty acid import into mitochondria. Biochim Biophys Acta. 1486(1):117. 
Kobayashi T, Shinnoh N, Kondo A (1997) Yamada T, Adrenoleukodystrophy protein-deficient mice represent abnormality of very long chain fatty acid metabolism., Biochem Biophys Res Commun; 232(3):631-6

Kovacs WJ; Tape KN; Shackelford JE; Wikander TM; Richards MJ; Fliesler SJ; Krisans SK; Faust PL (2009) Peroxisome deficiency causes a complex phenotype because of hepatic SREBP/Insig dysregulation associated with endoplasmic reticulum stress., J Biol Chem; 284(11):7232-45

Kovacs WJ, Tape KN, Shackelford JE, Duan X, Kasumov T, Kelleher JK, Brunengraber H, Krisans SK (2007) Localization of the pre-squalene segment of the isoprenoid biosynthetic pathway in mammalian peroxisomes. Histochem Cell Biol. 127(3):273-90.

Kunau WH (2005) Peroxisome biogenesis: end of the debate. Curr Biol15(18):R774-776.

Lake BG, Gray TJ (1985) Species differences in hepatic peroxisome proliferation. Biochem Soc Trans 13(5):859-861.

Lamhonwah AM, Ackerley CA, Tilups A, Edwards VD, Wanders RJ, Tein I (2005) OCTN3 is a mammalian peroxisomal membrane carnitine transporter. Biochem Biophys Res Commun 338(4):1966-72.

Lazarow PB, De Duve C (1976) A fatty acyl-CoA oxidizing system in rat liver peroxisomes: enhancement by clofibrate, a hypolipidemic drug. Proc Natl Acad Sci USA 73:2043-2046.

Lazarow PB, Fujiki Y (1985) Biogenesis of peroxisomes. Annu Rev Cell Biol 1:489-530. 
Lazarow PB. (2003) Peroxisome biogenesis: advances and conundrums. Curr Opin Cell Biol 15(4):489-497

Li X, Baumgart E, Dong GX, Morrell JC, Jimenez-Sanchez G, Valle D, Smith KD, Gould SJ (2002) PEX11alpha is required for peroxisome proliferation in response to 4-phenylbutyrate but is dispensable for peroxisome proliferator-activated receptor alpha-mediated peroxisome proliferation., Mol Cell Biol; 22(23):8226-40

Li X, Baumgart E, Morrell JC, Jimenez-Sanchez G, Valle D, Gould SJ (2002) PEX11 beta deficiency is lethal and impairs neuronal migration but does not abrogate peroxisome function., Mol Cell Biol; 22(12):4358-65 (b)

Lu JF, Lawler AM, Watkins PA, Powers JM, Moser AB, Moser HW (1997) Smith KD, A mouse model for X-linked adrenoleukodystrophy., Proc Natl Acad Sci U S A; 94(17):9366-71

Mannaerts GP, van Veldhoven PP (1996) Functions and organization of peroxisomal betaoxidation. Ann N Y Acad Sci 804:99-115.

Maxwell M, Bjorkman J, Nguyen T, Sharp P, Finnie J, Paterson C, Tonks I, Paton BC, Kay GF, Crane DI (2003) Pex13 inactivation in the mouse disrupts peroxisome biogenesis and leads to a Zellweger syndrome phenotype., Mol Cell Biol; 23(16):5947-57

Michelakakis HM, Zafeiriou DI, Moraitou MS, Gootjes J, Wanders RJ (2004) PEX1 deficiency presenting as Leber congenital amaurosis. Pediatr Neurol. 31(2):146-9 
Miyazawa S, Osumi T, Hashimoto T (1980) The presence of a new 3-oxoacyl-CoA thiolase in rat liver peroxisomes. Eur J Biochem 103(3):589-596.

Moser HW (2006) Therapy of X-linked adrenoleukodystrophy. NeuroRx. 3(2):246-53.

Moser HW, Raymond GV, Lu S-E, Muenz LR, Moser AB, Xu J, Jones RO, Loes DJ, Melhem ER, Dubey P, Bezman L, Brereton NH, Odone A. (2005) Follow-up of 89 asymptomatic patients with adrenoleukodystrophy treated with Lorenzo's Oil. Arch Neurol. 62;1073-80)

Mullen RT, Flynn CR, Trelease RN (2001) How are peroxisomes formed? The role of the endoplasmic reticulum and peroxins. Trends Plant Sci 6:256-262.

Mullen RT, Trelease RN (2000) The sorting signals for peroxisomal membrane-bound ascorbate peroxidase are within its C-terminal tail. J Biol Chem 275:16337-13644

Nemali MR, Usuda N, Reddy MK, Oyasu K, Hashimoto T, Osumi T, Rao MS, Reddy JK (1988) Comparison of constitutive and inducible levels of expression of peroxisomal beta-oxidation and catalase genes in liver and extrahepatic tissues of rat. Cancer Res 48(18):5316-5324.

Novikoff B, Shin WY (1964) The endoplasmic reticulum in the Golgi zone and its relations to microbodies, Golgi apparatus, and autophagic vacuoles in rat liver cells. J. Microsc. (Paris) 3:187206.

Okumoto K, Abe I, Fujiki Y (2000), Molecular anatomy of the peroxin Pex12p: ring finger domain is essential for Pex12p function and interacts with the peroxisome-targeting signal type 1-receptor Pex5p and a ring peroxin, Pex10p. J Biol Chem 275(33):25700-25710. 
Olivier LM, Chambliss KL, Gibson KM, Krisans SK (1999) Characterization of phosphomevalonate kinase: chromosomal localization, regulation and subcellular targeting. J. Lipid Res. 40:672-679.

Olivier LM, Kovacs W, Masuda K, Keller GA, Krisans SK (2000) Identification of peroxisomal targeting signals in cholesterol biosynthetic enzymes: AA-CoA thiolase, HMG-CoA synthase, MPPD, and FPP synthase. Journal of Lipid Research, Vol. 41, 1921-1935

Paton VG, Shackelford JE, Krisans SK (1997) Cloning and subcellular localization of hamster and rat isopentenyl diphosphate dimethylally diphosphate isomerase. A PTS1 motif targets the enzyme to peroxisomes. J. Biol. Chem. 272:18945-18950.

Pedersen JI (1993) Peroxisomal oxidation of the steroid side chain in bile acid formation. Biochimie 75: $159-165$.

Peters JM, Cheung C, Gonzalez FJ (2005), Peroxisome proliferator-activated receptor-alpha and liver cancer: where do we stand? J Mol Med 83(10):774-85

Pujol A, Ferrer I, Camps C, Metzger E, Hindelang C, Callizot N, Ruiz M, Pàmpols T, Giròs M, Mandel JL (2004) Functional overlap between ABCD1 (ALD) and ABCD2 (ALDR) transporters: a therapeutic target for X-adrenoleukodystrophy. Hum Mol Genet; 13(23):2997-3006.

Purdue PE, Lazarow PB (2001) Peroxisome biogenesis. Annu Rev Cell Dev Biol 17:701-752. 
Qi C, Zhu Y, Pan J, Usuda N, Maeda N, Yeldandi AV, Rao MS, Hashimoto T, Reddy JK (1999) Absence of spontaneous peroxisome proliferation in enoyl-CoA Hydratase/L-3-hydroxyacyl-CoA dehydrogenase-deficient mouse liver. Further support for the role of fatty acyl CoA oxidase in PPARalpha ligand metabolism., J Biol Chem; 274(22):15775-80

Reddy JK (2004) Peroxisome proliferators and peroxisome proliferator-activated receptor alpha: biotic and xenobiotic sensing. Am J Pathol, 164(6):2305-2321.

Reddy JK, Hashimoto T (2001) Peroxisomal beta-oxidation and peroxisome proliferator-activated receptor alpha: an adaptive metabolic system. Annu Rev Nutr 21:193-230.

Reddy JK, Mannaerts GP (1994) Peroxisomal lipid metabolism. Annu Rev Nutr 14:343-70.

Reddy JK, Reddy MK, Usman MI, Lalwani ND, Rao MS (1986), Comparison of hepatic peroxisome proliferative effect and its implication for hepatocarcinogenicity of phthalate esters, di(2-ethylhexyl) phthalate, and di(2-ethylhexyl) adipate with a hypolipidemic drug. Environ Health Perspect 65:317-27.

Rhodin J (1954) Correlation of ultrastuctural organization and function in normal an experimentally changed proximal convoluted tubule cells of the mouse kidney. $\mathrm{PhD}$ thesis, Aktiebolagetn Godvil, Stockholm.

Richert L, Price S, Chesne C, Maita K, Carmichael N (1996) Comparison of the induction of hepatic peroxisome proliferation by the herbicide oxadiazon in vivo in rats, mice, and dogs and in vitro in rat and human hepatocytes. Toxicol Appl Pharmacol 141(1):35-43. 
Rinaldo P, Matern D, Bennett MJ (2002) Fatty acid oxidation disorders. Annu Rev Physiol, 64, pp. 477-502.

Rodemer C, Thai TP, Brugger B, Kaercher T, Werner H, Nave KA, Wieland F, Gorgas K, Just WW (2003) Inactivation of ether lipid biosynthesis causes male infertility, defects in eye development and optic nerve hypoplasia in mice., Hum Mol Genet; 12(15):1881-95

Sacksteder KA, Jones JM, South ST, Li X, Liu Y, Gould SJ (2000) PEX19 binds multiple peroxisomal membrane proteins, is predominantly cytoplasmic, and is required for peroxisome membrane synthesis. J Cell Biol 148(5):931-944.

Salido EC, Li XM, Lu Y, Wang X, Santana A, Roy-Chowdhury N, Torres A, Shapiro LJ, RoyChowdhury J (2006) Alanine-glyoxylate aminotransferase-deficient mice, a model for primary hyperoxaluria that responds to adenoviral gene transfer., Proc Natl Acad Sci U S A; 103(48):1824954

Savolainen K, Kotti TJ, Schmitz W, Savolainen TI, Sormunen RT, Ilves M, Vainio SJ, Conzelmann E, Hiltunen JK (2004) A mouse model for alpha-methylacyl-CoA racemase deficiency: adjustment of bile acid synthesis and intolerance to dietary methyl-branched lipids., Hum Mol Genet; 13(9):955-65

Schrader M, Fahimi HD (2006) Peroxisomes and oxidative stress. Biochim Biophys Acta. 1763(12):1755-66 
Seedorf U, Brysch P, Engel T, Schrage K, Assmann G (1994) Sterol carrier protein X is peroxisomal 3-oxoacyl coenzyme A thiolase with intrinsic sterol carrier and lipid transfer activity. J Biol Chem 269(33):21277-21283.

Setchell KDR, O'Connell NC (2001) in Liver Disease in Children (Suchy FJ, Sokol RJ, Balistreri WF, eds), 2nd Ed. , pp. 701-733, Lippincott Williams \& Wilkins, Philadelphia

Shani N, Valle D (1996) A Saccharomyces cerevisiae homolog of the human adrenoleukodystrophy transporter is a heterodimer of two half ATP-binding cassette transporters. Proc Natl Acad Sci USA. 93(21):11901-6.

Shimizu N, Itoh R, Hirono Y, Otera H, Ghaedi K, Tateishi K, Tamura S, Okumoto K, Harano T, Mukai S, Fujiki Y. (1999) The peroxin Pex14p. cDNA cloning by functional complementation on a Chinese hamster ovary cell mutant, characterization, and functional analysis. J Biol Chem 274(18):12593-12604.

Shimozawa N (2007) Molecular and clinical aspects of peroxisomal diseases. J Inherit Metab Dis. 30(2):193-7.

Shimozawa N, Tsukamoto T, Nagase T, Takemoto Y, Koyama N, Suzuki Y, Komori M, Osumi T, Jeannette G, Wanders RJ, Kondo N. (2004) Identification of a new complementation group of the peroxisome biogenesis disorders and PEX14 as the mutated gene. Hum Mutat 23(6):552-558.

Singh I, Pahan K, Khan M (1998) Lovastatin and sodium phenylacetate normalize the levels of very long chain fatty acids in skin fibroblasts of X-adrenoleukodystrophy. FEBS Lett. 426(3):342-6. 
Sprecher H (1992) in Polyunsaturated Fatty Acids in Human Nutrition (Bracco U, Deckelbaum R J, eds), pp. 13-24, Nestec Ltd., Vevey/Raven Press, Ltd., New York

Steinberg SJ, Dodt G, Raymond GV, Braverman NE, Moser AB, Moser HW (2006) Peroxisome biogenesis disorders. Biochim Biophys Acta. 1763(12):1733-48

Stolz DB, Zamora R, Vodovotz Y, Loughran PA, Billiar TR, Kim YM, Simmons RL, Watkins SC (2002) Peroxisomal localization of inducible nitric oxide synthase in hepatocytes. Hepatology 36(1):81-93.

Su HM, Moser AB, Moser HW, Watkins PA (2001) Peroxisomal Straight-chain Acyl-CoA Oxidase and D-bifunctional Protein Are Essential for the Retroconversion Step in Docosahexaenoic Acid Synthesis, J. Biol. Chem., Vol. 276, Issue 41, 38115-38120.

Subramani S, Koller A, Snyder WB (2000) Import of peroxisomal matrix and membrane proteins. Annu Rev Biochem 69:399-418.

Subramani S. (1993) Protein import into peroxisomes and biogenesis of the organelle. Annu Rev Cell Biol 9:445-478.

Swinkels BW, Gould SJ, Bodnar AG, Rachubinski RA, Subramani S (1991) A novel, cleavable peroxisomal targeting signal at the amino-terminus of the rat 3-ketoacyl-CoA thiolase. Embo J, 10(11):3255-3262. 
Thompson SL, Krisans SK (1990) Rat liver peroxisomes catalyze the initial step in cholesterol synthesis: the condensation of acetyl-CoA units into acetoacetyl-CoA. J. Biol. Chem. 25:57315735.

Thoms S, Erdmann R (2005) Dynamin-related proteins and Pex11 proteins in peroxisome division and proliferation. FEBS J. 272(20):5169-81

Titorenko VI, Rachubinski RA (1998) The endoplasmic reticulum plays an essential role in peroxisome biogenesis. Trends Biochem Sci 23(7):231-3.

van den Bosch H, Schutgens RB, Wanders RJ, Tager JM (1992) Biochemistry of peroxisomes. Annu Rev Biochem 61:157-197.

Vlahcevic ZR, Pandak WM, Stravitz RT (1999) Gastroenterol Cli. North A. 28, 1-25

Wanders RJ (2004) Peroxisomes, lipid metabolism, and peroxisomal disorders. Mol Genet Metab 83(1-2):16-27.

Wanders RJ, van Grunsven EG, Jansen GA (2000) Lipid metabolism in peroxisomes: enzymology, functions and dysfunctions of the fatty acid alpha- and beta-oxidation systems in humans. Biochem Soc Trans 28:141-9.

Wanders RJ, Vreken P, Ferdinandusse S, Jansen GA, Waterham HR, van Roermund CW, Van Grunsven EG (2001) Peroxisomal fatty acid alpha- and beta-oxidation in humans: enzymology, peroxisomal metabolite transporters and peroxisomal diseases. Biochem Soc Trans; 29(Pt 2):25067. 
Wanders RJ, Waterham HR (2005) Peroxisomal disorders I: biochemistry and genetics of peroxisome biogenesis disorders. Clin Genet 67(2):107-133.

Watkins PA, Lu JF, Steinberg SJ, Gould SJ, Smith KD, Braiterman LT (1998) Disruption of the Saccharomyces cerevisiae FAT1 gene decreases very long-chain fatty acyl-CoA synthetase activity and elevates intracellular very long-chain fatty acid concentrations. J Biol Chem. 273(29):18210-9

Wierzbicki AS (2007) Peroxisomal disorders affecting phytanic acid alpha-oxidation: a review. Biochem Soc Trans. 35(Pt 5):881-6.

Zhang X, Tanaka N, Nakajima T, Kamijo Y, Gonzalez FJ, Aoyama T. (2006) Peroxisome proliferator-activated receptor alpha-independent peroxisome proliferation. Biochem Biophys Res Commun. 11;346(4):1307-11. 


\section{Table 1. Peroxisomal disorders}

Peroxisomal enzyme/transporter deficiencies (PEDs)

Rhizomelic chondrodysplasia punctata Type 2 (DHAPAT deficiency)

Rhizomelic chondrodysplasia punctata Type 3 (alkyl-DHAP synthase)

X-linked adrenoleukodystrophy

Acyl-CoA oxidase deficiency

D-bifunctional protein deficiency

2-MethylacylCoA racemase deficiency

Sterol carrier protein $\mathrm{X}$ deficiency

Refsum disease (phytanoyl-CoA hydroxylase deficiency)

Hyperoxaluria Type 1

Acatalasaemia

Peroxisome biogenesis disorders (PBDs)

Zellweger spectrum disorders, ZSDs

Zellweger syndrome, ZS

Neonatal adrenoleukodystrophy, NALD

Infantile Refsum disease, IRD 


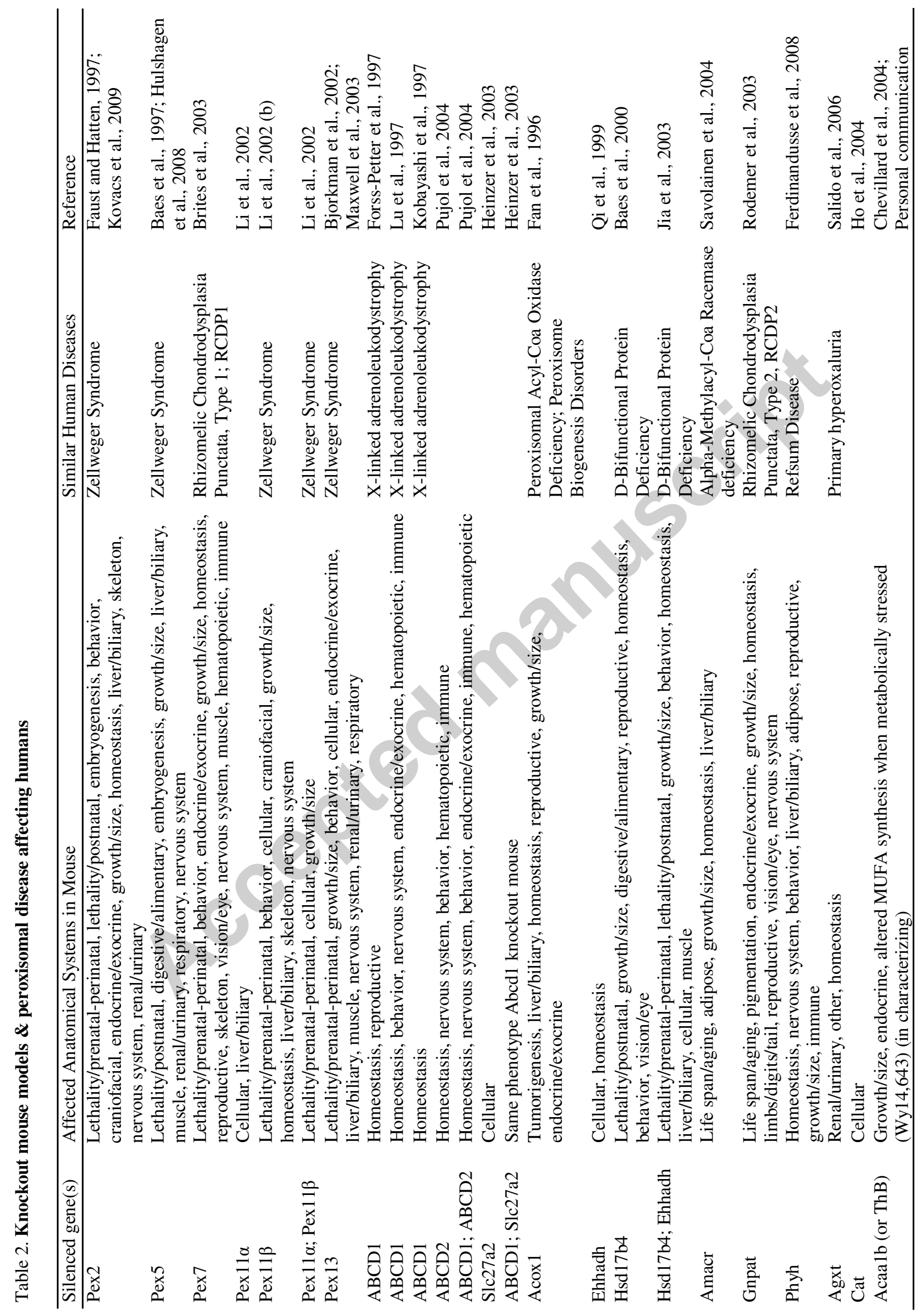




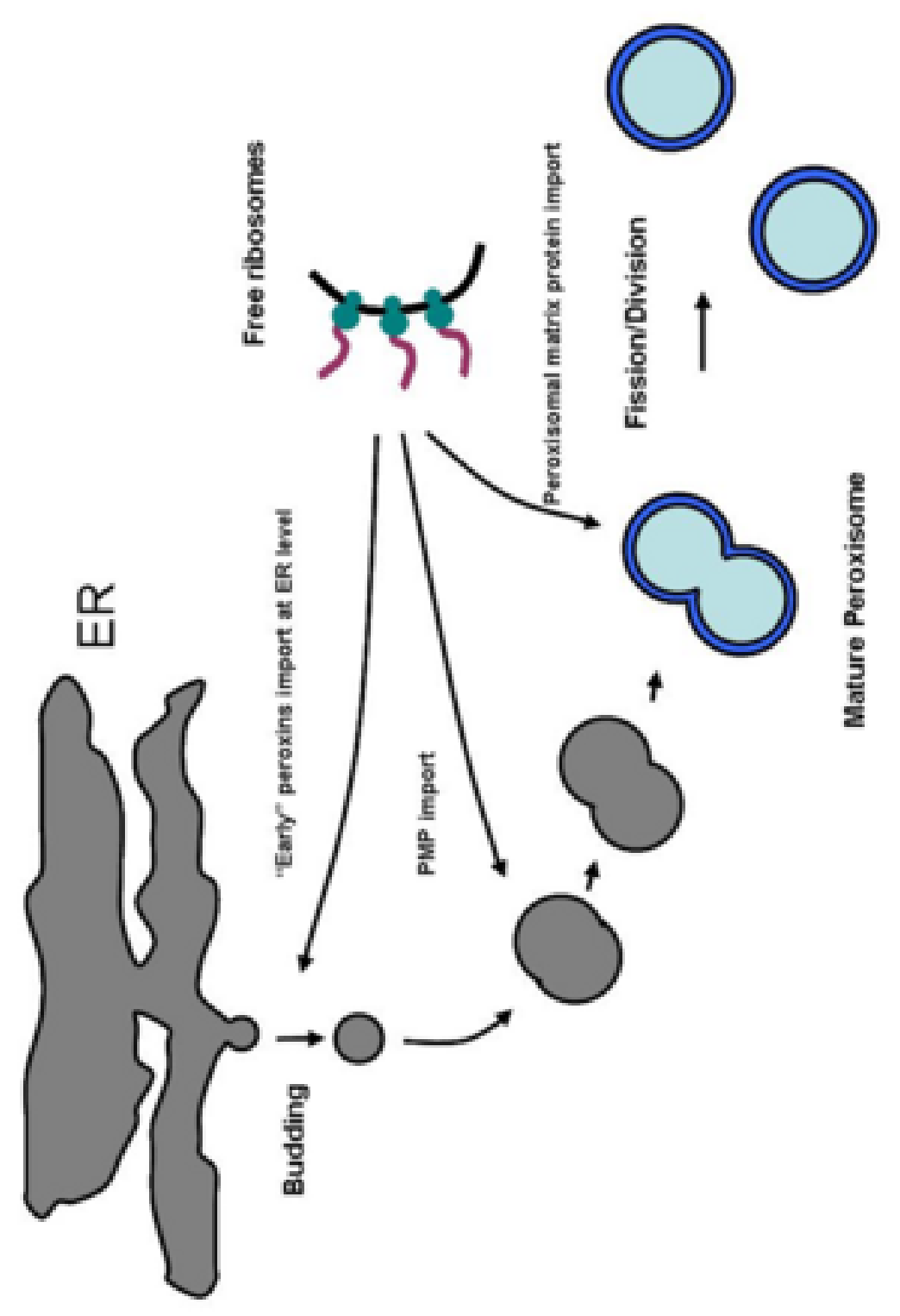

$\frac{\bar{d}}{\frac{\pi}{5}}$ 


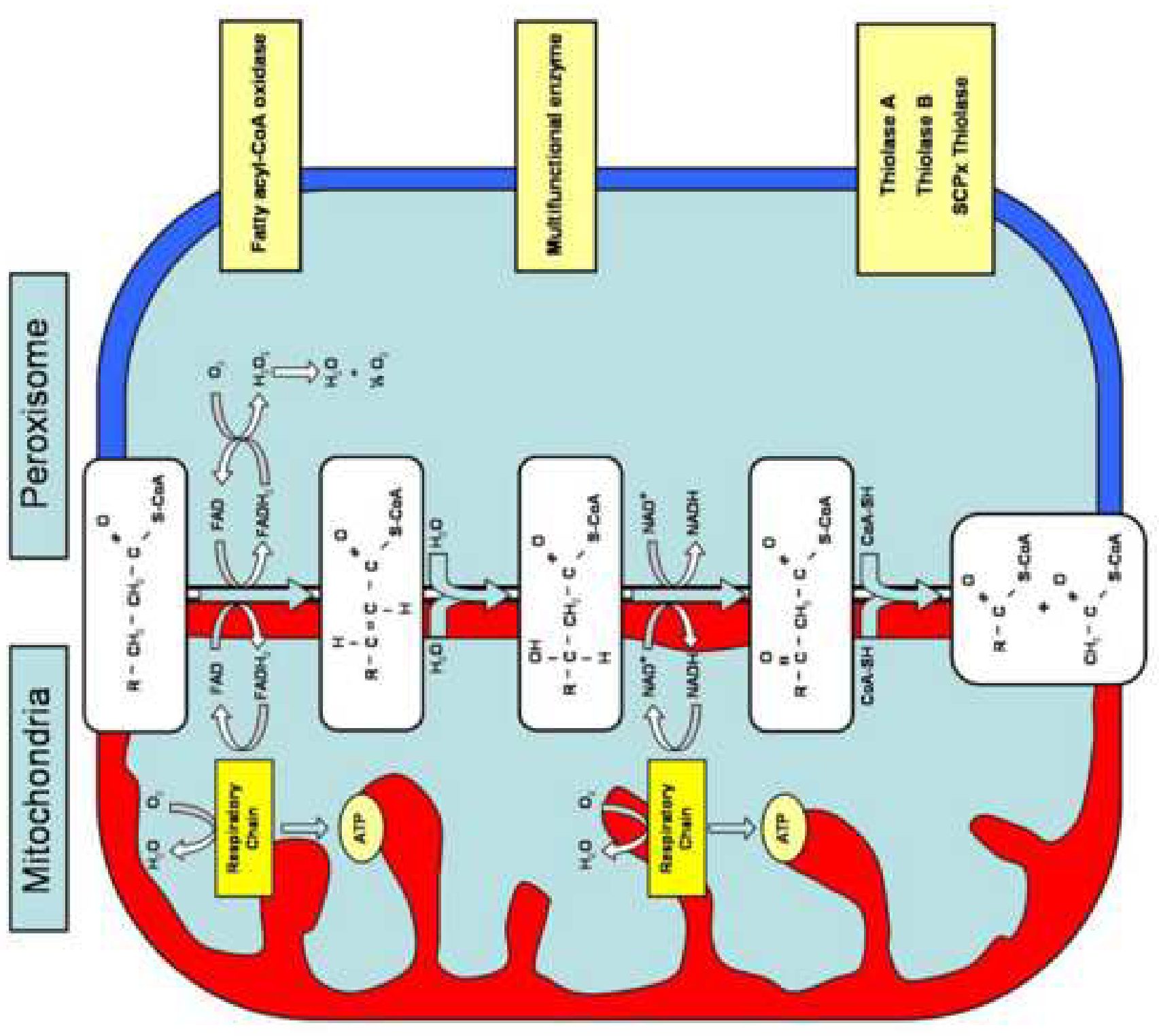




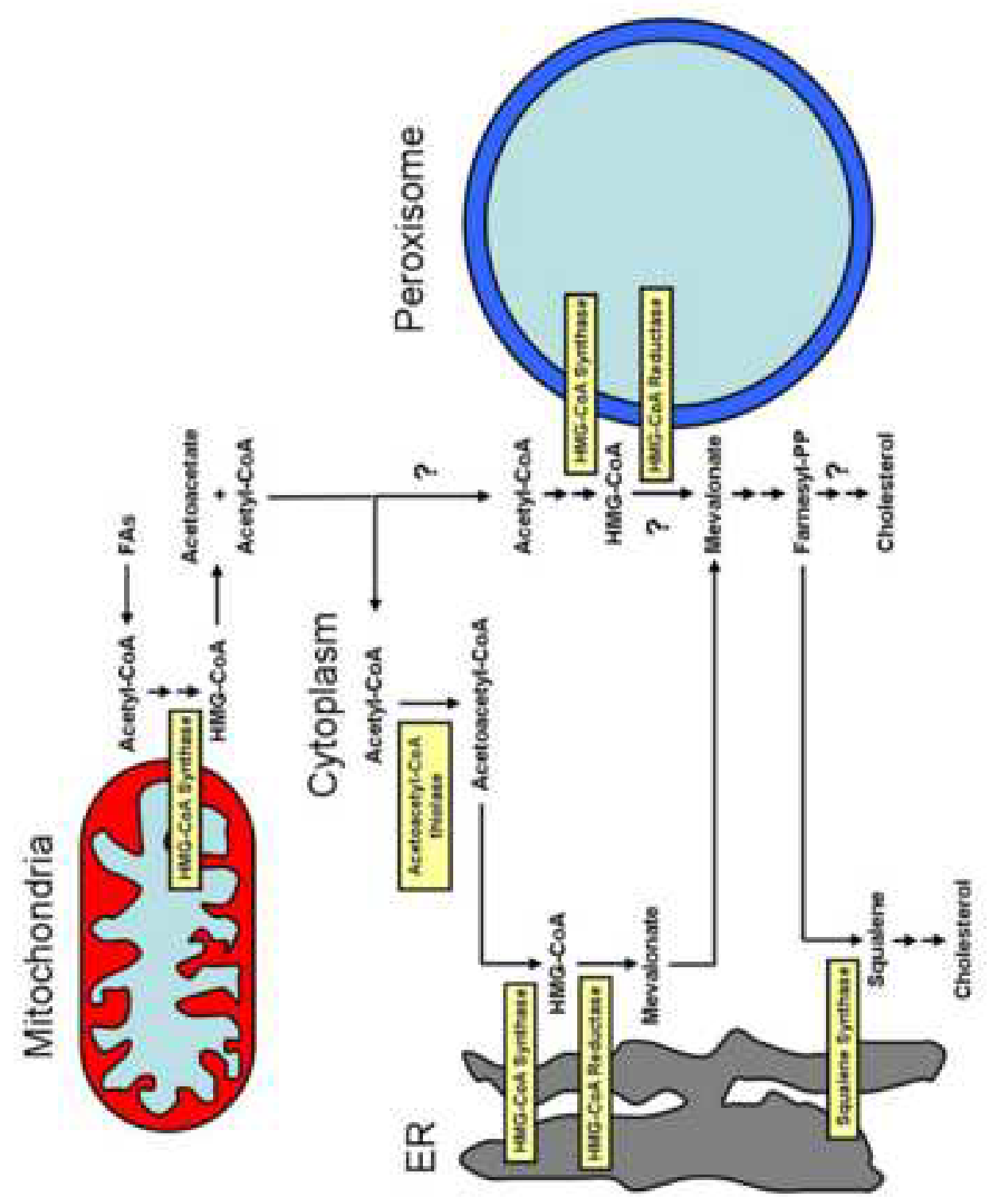

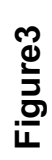




\section{Legend}

Figure 1. Model of peroxisome biogenesis. ER is involved in de novo biogenesis of peroxisome. Mature peroxisomes acquire proteins from free ribosomes and can proliferate by division (adapted from Thoms and Erdmann, 2005, and Holroyd and Erdmann, 2001)

Figure 2. Mechanism of $\beta$-oxidation in peroxisome and mitochondria. The mechanism by which fatty acids are degraded in peroxisomes and mitochondria is identical. Each pathway contains enzymes encoded by different genes. On the right side of the figure are shown the enzyme found in the peroxisome of the rodents and involved in peroxisomal $\beta$-oxidation (modified from www.biocarta.com/pathfiles/boxnpPathway.asp)

Figure 3. Cholesterol biosynthesis. The synthesis of cholesterol is carried out in different cell organelles, i.e. mitochondria, peroxisome and ER. The question marks indicate the probably pathways not yet confirmed (modified by Kovacs et al., 2007)

Table 1: Peroxisomal disorders

Table 2. Knockout mouse models \& peroxisomal disease affecting humans. The table lists the silenced gene in knockout mouse models and the main observable consequences. Abbreviations: Pex $11 \alpha$ (peroxisomal biogenesis factor $11 \alpha$ ), Pex $11 \beta$ (peroxisomal biogenesis factor $11 \beta$ ), Pex13 (peroxisomal biogenesis factor 13), Pex5 (peroxisomal biogenesis factor 5), Pex2 (peroxisomal membrane protein 2), Pex7 (peroxisomal biogenesis factor 7), ABCD1 (ATP-binding cassette, subfamily D [ALD], member 1), ABCD2 (ATP-binding cassette, sub-family D [ALD], member 2), Slc27a2 (solute carrier family 27 [fatty acid transporter], member 2), Acox1 (acyl-Coenzyme A oxidase 1, palmitoyl), Ehhadh (enoyl-Coenzyme A, hydratase/3-hydroxyacyl Coenzyme A 
dehydrogenase), Hsd17b4 (hydroxysteroid [17-beta] dehydrogenase 4), Amacr (alpha-methylacylCoA racemase), Gnpat (glyceronephosphate O-acyltransferase), Phyh (phytanoyl-CoA hydroxylase), Agxt (alanine-glyoxylate aminotransferase), Cat (catalase), Acaalb ( or ThB) (acetylCoenzyme A acyltransferase 1B). 